\title{
doispontos:
}

\section{Marx em três tempos de Florestan ${ }^{1}$}

\author{
Lidiane Soares Rodrigues \\ lsr@ufscar.br \\ Departamento de Ciências Sociais, Universidade Federal de São Carlos (UFSCar), São Carlos, Brasil
}

Resumo: O presente trabalho situa, institucionalmente, as publicações de Florestan Fernandes que versam a respeito de Karl Marx. O objetivo consiste em caracterizar uma condicionante da variação das leituras de Marx realizadas pelo sociólogo. A realização deste intento pressupõe desvencilhar-se das categorias classificatórias convencionais da trajetória e da obra de Florestan Fernandes, para, em seguida, reconstituir três séries cronológicas em paralelo, que correspondem: à sua carreira (social, intelectual e política), aos interlocutores de referência, sociologicamente relevantes em cada momento dela, e aos textos publicados por ele sobre Karl Marx. O conteúdo das publicações sobre Marx, realizadas por Florestan Fernandes, torna-se inteligível por meio do entrelaçamento dessas séries.

Palavras-chave: sociologia da leitura e dos intelectuais; marxismo; Ciências Sociais brasileiras; Florestan Fernandes; trajetórias.

\section{Marx in three times of Florestan}

Abstract: This research identified the publications of Florestan Fernandes which dealt with the work of Karl Marx from an institutional point of view. The objective of this study is to characterize a constraining variation of Marx's readings conducted by the sociologist. This purpose requires extricating from conventional classificatory categories of trajectory and Florestan Fernandes' work, and then reconstituting a three-time series in parallel: his career (social, intellectual and political), the reference interlocutors - sociologically relevant in every moment of it, and the texts he published about Karl Marx. The contents of the publications by Florestan Fernandes on Marx become understandable by the interweaving of these series.

Keywords: sociology of reading and intellectuals; marxism; brazilian Social Sciences; Florestan Fernandes; trajectories.

“... as teorias e as escolas, como os micróbios e os glóbulos, se entredevoram e asseguram com a luta a continuidade da vida...”

Marcel Proust.

\section{INTRODUÇÃO}

A apresentação das leituras que o sociólogo Florestan Fernandes realizou de Karl Marx poderia ser realizada de numerosas maneiras. Entrementes, por variadas que elas sejam, implicam a adoção de uma perspectiva analítica concernente aos intelectuais, à história intelectual do marxismo e das ciências sociais, particularmente no Brasil e em São Paulo. Portanto, a título preliminar, explicita-se a concepção adotada, neste trabalho, a respeito destes três eixos temáticos. É no interior desta escolha que ele estabelece seus objetivos, sendo apropriado que seja ajuizado por sua congruência com ela. 
Os estudos a respeito dos intelectuais, e particularmente, cientistas e literatos engajados à esquerda e à direita, podem ser divididos em dois paradigmas opostos, segundo Frédérique Matonti e Gisèle Sapiro. De um lado, os estudos interessados em reproduzir o "gesto fundador do 'J'accuse" que corresponda aos intelectuais que elegem como objeto e modelo de admiração ou rechaço. Em geral, apresentam as ideias dos autores (por meio de balanços bibliográficos, paráfrases, exegeses) ligando-os a seus contextos macro-político e situando-os no contencioso político e heroico de suas trajetórias públicas. De outro lado, encontram-se os estudos que se propõem a explicar as tomadas de posição por meio do nexo entre disposição cognitiva e posição objetiva dos intelectuais no espaço social. Tendo por paradigma a teoria de Pierre Bourdieu, estes estudos partem da caracterização do espaço social que orienta os agentes na elaboração de suas obras, atentando para os aliados e adversários de suas lutas e demonstram, nas tomadas de posição, os interesses desinteressados típicos do mercado de bens simbólicos (MATONTI; SAPIRO, 2009, p. 5).

Esta linha divisória apresenta-se nitidamente nos trabalhos a respeito das ciências sociais no Brasil (KEINERT, 2011). Já no que tange ao marxismo, os trabalhos correspondem ao primeiro tipo de estudos mencionado, de modo que esta divisa não se estabeleceu entre eles. A bibliografia estrangeira a respeito da história do marxismo, ao menos aquela reunida por Eric Hobsbawm, também não apresenta a mencionada divisão, embora o historiador se evidencie preocupado com o problema na base dela: "(a história do marxismo) não pode ser apenas a história do que os marxistas (...) pensaram, escreveram e discutiram, uma história que se explicite na tradicional reconstrução da árvore genealógica das ideias (...)” (HOBSBAWM, 1983, p. 12). A contenção de nervos britânica impediu que zombasse seus colegas, auxiliado pelo jovem Marx esculhambando o "divertimento científico" de "explicar as curiosidades de formulações teóricas nebulosas" como se o fundamento delas não estivesse "nas relações terrenas reais" (MARX; ENGELS, 2007, p. 44). Constata-se, permanecendo no escopo da bibliografia estrangeira, que o interesse incessante pelo marxismo não alterou substancialmente os parâmetros dos estudos voltados a ele. Porém, suscitou iniciativas isoladas, sem o impacto da coleção organizada pelo historiador inglês, orientadas para o segundo paradigma supramencionado - o que defende serem as posições objetivas no espaço social fatores explicativos das tomadas de posição políticas - e não o contrário (BRUN, 2014; GOUARNÉ, 2013; MATONTI, 2005).

Dois motivos principais motivam a presente pesquisa a adotar este paradigma. Por um lado, o acúmulo de estudos no âmbito do paradigma oposto - tanto no que concerne ao marxismo quanto às ciências sociais; por outro, sua verve heurística, potencialmente reveladora de nexos de sentido ignorados por estes trabalhos. Adotá-la para tratar das leituras brasileiras de Karl Marx implica ter em vista o espaço dos leitores e das leituras organizado em torno dos campos político-partidário e do científico-pesquisa, propondo-se a caracterizar a relação entre ambos: quais são os agentes que estão em ambos os circuitos, a qual ordem de constrangimentos suas produções respondem nas suas diferentes fases, quais são a permeabilidade e a hierarquia de temas, obras, autores, comentadores - e, no limite: qual a relação entre o sistema partidário nacional, o sistema de ensino correspondente e a estrutura de oportunidades de trabalho na burocracia de Estado, viabilizada pelos capitais específicos das trajetórias que se fazem entre estes dois sistemas. ${ }^{2}$

É por se filiar a esta perspectiva mais ampla a respeito dos intelectuais, das ciências sociais e do marxismo, que o presente trabalho situa institucionalmente as publicações de Florestan Fernandes a respeito de Karl Marx, realizando uma leitura delas subordinada aos propósitos deste paradigma analítico. ${ }^{3} \mathrm{O}$ objetivo consiste em por em relevo uma condicionante da variação das leituras de Marx realizadas pelo sociólogo recorte imposto pela extensão possível deste artigo. A realização deste intento pressupõe dois movimentos prévios: desvencilhar-se das categorias classificatórias convencionais da trajetória e da obra de Florestan Fernandes; e, em seguida, a reconstituição de três séries cronológicas em paralelo, que correspondem: à sua carreira (social, intelectual e política), aos interlocutores de referência, sociologicamente relevantes 
em cada momento dela, aos textos publicados por ele sobre Karl Marx. O conteúdo das publicações sobre Marx, realizadas por Florestan Fernandes, tornam-se inteligíveis por meio do entrelaçamento destas séries.

A respeito destes dois procedimentos preliminares faz-se imperativa uma ponderação. As categorias de classificação correntes da trajetória, da obra e do "Marx/marxismo" de Florestan Fernandes correspondem de modo próprio ao primeiro paradigma supramencionado: repetem o que o sociólogo pensou a respeito do tema que interessa aos comentadores de sua obra. Além de exigir numerosos acordos tácitos, deixar-se apreender por tais categorias classificatórias implicaria ignorar a lei que rege a elaboração das mesmas privilégio interdito pelo paradigma teórico escolhido (BOURDIEU, 2001, p. 19). Uma das características definidoras do processo de consagração dos intelectuais consiste na proliferação de "porta-vozes" de suas ideias. Por um lado, os comentadores classificam, delimitam, consagram e engessam a obra do autor comentado numa agenda de leituras lentamente rotinizada; por outro, situam-se em seu próprio espaço (de geração, de disciplina, de opção política) a partir da categoria construída para o autor e auferem empréstimos do capital simbólico do nome em vias consagração. No caso em tela, elas induzem a um conjunto limitado e rotinizado de questões: as fases de mais ou menos radicalismo político e aderência à vida profissional, as identificações teóricas, disciplinares e temáticas. Possivelmente, a despeito das intenções de seus elaboradores, estas questões, induzidas pelas categorias classificatórias correntes da obra/trajetória de Florestan Fernandes delimitaram perguntas incontornáveis e eliminaram outras. Tudo se passa como se fosse impossível propor algo sobre o autor sem tomar posição previamente a respeito de ele ter sido ou não "reformista" ou "revolucionário" e, naturalmente, estabelecer os termos desta ruptura, seja numa fase da trajetória (vida), seja no "arremate da reflexão" (obra, conceito, teoria). Daí discutir-se o conceito de "revolução burguesa"; o "intelectual" e o "político"; e, como não poderia deixar de ser, seu "ecletismo bem temperado" e as fronteiras disciplinares, cujo rígido ponto de partida esconde menos do que denuncia o objetivo da discussão: sentenciar sua versatibilidade, a interdisciplinaridade, e solidariedade para com todos os grupos deserdados da ordem (daí, segundo platitude corrente, ter se ocupado de negros quando atrelado à Sociologia; de índios, quando à Antropologia). ${ }^{4}$ Na impecável formulação de sua filha, Heloisa Fernandes - "(meu pai) dá voz a um sem número de aspirações de mudança na sociedade brasileira" (FERNANDES, 2005). A constatação é repleta de consequências e sutis induções de interpretação das relações entre marxismo e ciência social, expressando-se no modo como Florestan Fernandes é lido e abordado. Parcialmente reféns do gerenciamento que o próprio sociólogo imprimiu a sua obra, cuja coerência e unidade estariam dadas por um radicalismo político permanente (BOURDIEU, 1986), estas discussões nem sempre atentam à historicidade da própria trajetória em questão, atribuindo a ela intenções que não orientaram constantemente sua ação, na mesma direção e intensidade. Por fim, com relação ao entrelaçamento das três séries (social, intelectual e política), e o destaque aos interlocutores sociologicamente relevantes em cada momento delas, valeria reiterar que o objetivo deste procedimento consiste em caracterizar suas disposições e sua posição no espaço (da ciência ou da política). É esta caracterização que torna inteligíveis as tomadas de posição do sociólogo, nas leituras e publicações que realizou de Marx. Esta advertência, talvez pedagógica para os familiarizados com o sistema teórico de Pierre Bourdieu, ainda é necessária. Embora a recepção de sua obra se avolume promovendo seu abrasileiramento (PINHEIRO FILHO, 2009), os procedimentos requeridos por ela permanecem estrangeiros. É comum o queixume vulgar dos que, ignorando-os, consideram-nos a serviço de uma história de intrigas. Ledo equívoco.

\section{O MARX DO JOVEM FLORESTAN}

A primeira publicação de Florestan Fernandes tratando de Karl Marx data de 1946 e consiste numa introdução ao texto Contribuição à Crítica da Economia Política, por ele traduzido a partir de edições de Marx em inglês, francês e espanhol, para a editora trotskista Flama, a convite de Hermínio Sacchetta (1909-1982). 
No biênio de 1944 e 1946, Florestan Fernandes havia concluído seu curso de Ciências Sociais (realizado entre 1940-1943), na Faculdade de Filosofia, Ciências e Letras da Universidade de São Paulo (FFCL-USP). Ele casava-se com Miriam, iniciava seu mestrado na Escola Livre de Sociologia e Política (ELSP) e se aproximava da movimentação cultural e política de fim do Estado Novo. Além disso, tornava-se amigo do jornalista da Folha da Manhã, Hermínio Sacchetta, ex-militante do PCB, então dirigente do PSR (Partido Socialista Revolucionário, de orientação trotskista). Sacchetta o recrutou para uma efêmera militância: Florestan frequentou reuniões, assinou o documento da Coligação Democrática Radical em 1945, com o qual os trotskistas tomavam parte nas eleições daquele ano, e foi responsabilizado pelo trabalho de tradução/introdução mencionado (SEREZA, 2005).

Pelo exposto acima, fica evidente que o sociólogo atravessava a fase da carreira social em que os processos de integração se realizam em meio a escolhas, renúncias e gerenciamento do tempo empenhado na política/militância, na profissão/trabalho universitário e na família/matrimônio. A militância exigia um dispêndio de tempo de que não dispunha, a não ser em detrimento de outras atividades. A conclusão da graduação, suas responsabilidades familiares (contrair matrimônio e se manter arrimo de família) e os esforços para ultrapassar a barreira que o deixava sempre em posições titubeantes no espaço da sociabilidade estudantil implicavam um investimento de tempo nas obrigações em detrimento de atividades que requerem tempo livre. Vale dizer que esta economia temporal corresponde aos cálculos práticos de alguém numa posição titubeante no espaço social. Um outro percurso poderia ter estas atividades bem articuladas, caso os meios sociais de circulação não fossem tão heterogêneos entre si e em relação às suas próprias origens, ou não tivesse que suplantar handicaps na acumulação de seu capital cultural. Lidas sob este prisma, as declarações de Antonio Candido a respeito de Florestan Fernandes (destacando sua seriedade e pouco interesse pela política nos anos 1940; em contraste com ele próprio, mais engajado e filiado por mais tempo no Partido Socialista Brasileiro) - ganham outro sentido (CANDIDO, 1996).

Uma imagem expressiva e sintética situaria Florestan Fernandes como um estranho em dois ninhos - o da militância política e o dos cursos universitários. Embora estes passassem por um processo de democratização, recrutando em camadas sociais remediadas e ascendentes, suas origens eram ainda mais modestas do que as da média das novas clientelas (LIMONGI, 2001). O mesmo é verificado quando se coteja profissões e origens sociais de seus companheiros de militância: eles são mais velhos e dotados de fonte de renda asseguradas. ${ }^{5}$ Seu isolamento - isto é, um modo específico de ser situado objetivamente face aos grupos de referência, por suas propriedades sociais excepcionais (esta origem modestíssima) - opera na integração e na integração com os dois grupos de referência. Entretanto, é no espaço acadêmico que "se estabelece uma relação particular entre as esperanças subjetivas e as oportunidades objetivas" (BOURDIEU, 2001, p. 260) que promove sua libido sciendi. Logo Florestan Fernandes abandona este grupo de militância para se dedicar inteiramente às suas titulações. Em fase posterior de sua trajetória, o sociólogo elaborou numerosas explicações a respeito de sua desistência da militância - oscilando sempre entre explicações objetivantes (ordem social e política) e subjetivas (GARCIA, 2002).

Há uma história da encomenda desta tradução/introdução e de suas publicações. A primeira se destinou à editora Flama e sofreu o corte de uma dezena de páginas; a segunda compôs o livro Ensaios de sociologia geral e aplicada, publicado em 1959, pela Livraria Pioneira Editora, na coleção "Biblioteca Pioneira de Ciências Sociais. Sociologia”. Indiscutivelmente "científica", nesta edição, o texto foi publicado sem cortes, e intitulado "Marx e o Pensamento Sociológico Moderno" - introdução que nunca foi publicada inteiramente senão neste livro, posto que as edições que recebeu posteriormente reproduziram a versão da editora Flama. Além deste texto, Florestan Fernandes apresenta outra publicação sobre Karl Marx, em 1959: "As soluções fundamentais dos problemas da indução em Sociologia: 3) Karl Marx", no livro Fundamentos empíricos da explicação sociológica. Esta publicação reunia o substancial do que Florestan 
Fernandes havia ministrado num Curso de extensão cultural, promovido em colaboração com a Secretaria de Educação do Estado de São Paulo e pela FFCL-USP, dirigido aos professores de sociologia de escolas normais oficiais, em janeiro de 1954.

A posição do sociólogo no espaço da política e no espaço da ciência não era a mesma em 1946 e 1959. A caracterização da curva ascensional que liga uma a outra, pode iluminar seu investimento nas publicações de 1959, assim como o conteúdo delas.

Do ponto de vista de seu percurso intelectual, a sucessão dos temas dos trabalhos produzidos para as titulações acadêmicas apresenta uma nítida direção, a do domínio do coração da matéria disciplinar: teoria e método, a partir de trabalhos empíricos de pesquisa. Assim, de Organização social dos Tupinambá (mestrado), passando então para $A$ função social da guerra na sociedade tupinambá (doutorado), "o autor faz um exercício de análise; em o Ensaio sobre o método de interpretação funcionalista na Sociologia pensa, a posteriori, sobre os limites e possibilidades dessa vertente metodológica" (ARRUDA, 1995, p. 148-149). Do ponto de vista institucional, assumir a cátedra de Sociologia I, na FFCL-USP, em 1954, por indicação por Roger Bastide, que a deixava para retornar a França, sucedia anos de intenso trabalho combinando ocupações remuneradas externas à vida intelectual a um regime de assistência a docentes (da Sociologia I e II) descomunal, além de um envolvimento exaustivo nas atividades de pesquisa sobre o negro, encomendada pela UNESCO. A conquista da cadeira coroava a "maturidade intelectual, evidente na tentativa de repensar os fundamentos teóricos da disciplina sociológica, através de uma das suas contribuições clássicas” (ARRUDA, 1995, p. 148), aliando a isso preocupações práticas relativas à investigação sociológica.

Destituído da rede social de apoio requerida para a organização coerente de um grupo de docência e pesquisa - expectativa inscrita nas práticas sociológicas desenvolvidas com Bastide - Florestan Fernandes tomou providências compensatórias dessa defasagem. Estava "ciente de que suas chances de afirmação intelectual encontravam-se diretamente ligadas à ampliação de seu poder institucional” (PONTES, 1998, p. 187), e para viabilizá-lo, não mediu esforços, calculou a composição dos capitais específicos de seus assistentes e para contratá-los, dirigiu-se ao governo do Estado, e a órgãos federais. Contraiu inimizades com alguns, mas angariou vantagens para todos. Seu empenho, particularmente no que se refira às contratações docentes, negociadas com Jânio Quadros, governador hostil à comunidade acadêmica, não beneficiou exclusivamente sua cadeira. Os numerosos relatórios que ele produziu imediatamente após a conquista da cátedra (1954-1960), justificando a necessidade de aumento dos recursos financeiros e humanos, destinados à FFCL-USP, na tentativa de sensibilizar o governo do Estado, consistem numa contrapartida de sua visão de ciência sociológica (RODRIGUES, 2012, p. 121-123). O sociólogo punha, então, "em andamento uma forma de reflexão sociológica absolutamente comprometida com a ideia universal de ciência e que se exprime no modo pelo qual constrói o seu discurso" (ARRUDA, 2001, p. 236), tomando distância do ensaísmo, priorizando questões ligadas ao desenvolvimento e à constituição da sociedade burguesa no Brasil.

Desse modo, ele formou a equipe mais dinâmica e coesa do cenário- jovens, "pelo menos" com a mesma capacidade de trabalho que ele, dispostos a atuar em conjunto e com uma agenda de pesquisa articulada em torno do tema da passagem da sociedade escravista à sociedade de classes no Brasil. Este programa esteve na base da formação e da titulação dos membros de sua cadeira. O círculo de seus assistentes foi meticulosamente calculado - considerando competências específicas e recursos econômicos e sociais - e conformava, hierarquicamente, os seguintes membros: Fernando Henrique Cardoso, Renato Moreira Jardim, Octavio Ianni, Maria Sylvia Carvalho Franco e Marialice Mencarini Foracchi. Junto com eles, Florestan esteve à frente do eixo paulista da Campanha pela Escola Pública - o envolvimento com as questões desta ordem nunca se dissociou das estratégias de disputa de seu grupo no interior do espaço científico. 
O conjunto de leitores de Karl Marx, sociologicamente relevantes para o espaço considerado, também havia mudado, em comparação ao de 1946, quando o sociólogo elaborou o primeiro texto da série em exposição. À altura da publicação encomendada pela Flama, no polo político, a interlocução com leitores partidários não interessava ao sociólogo. Em contrapartida, a edição da Editora Flama não foi arbitrária. Quase metade do texto foi eliminado: a diferença da quantidade das notas na versão completa (59) e na versão editada (26) dá ideia disso. Os trechos não foram editados de maneira contínua, havendo dois grandes cortes - um de treze parágrafos; os comentários de Florestan a leituras de Marx que qualifica como "equivocadas"; por fim, três parágrafos e meio (longos, mesmo para o padrão de escrita do sociólogo, apreciador de parágrafos extensos). Decerto, edições desta ordem sugerem muitas explicações. Por exemplo, é possível notar algumas repetições de argumentos no texto - e neste caso, a eliminação se prestaria e torná-lo enxuto. Porém, lido em sua integridade, elas parecem mínimas, atendendo mais a propósitos de organização do raciocínio do autor. Ou ainda: possíveis restrições de custo editorial tenham obrigado a edição. Ainda que este motivo entre em linha de conta, o exame da coerência interna dos trechos eliminados impõe-se. Cotejando o texto publicado em 1946, com o original/completo, publicado em 1959, o contraste e o exame detalhado dos trechos evidenciam uma unidade - a saber: as preocupações do jovem Florestan com relação às possibilidades lógicas e históricas da Sociologia como ciência moderna. ${ }^{6}$ Absorvido crescentemente pelos parâmetros acadêmicos de trabalho, escreveu seguindo rumos diversos do que esperava a editora, apoiando-se, proporcionalmente mais em cientistas sociais do que em marxistas/marxólogos. ${ }^{7}$ Discutiu a posição de Marx junto à ciência moderna e empenhou-se em articular suas contribuições metodológicas ao problema que mobiliza os cientistas em fases de constituição institucional, isto é, às condições de possibilidade da segmentação em domínios próprios das áreas do saber (ARRUDA, 2001, p. 238). O interesse desta orientação de leitura reside em que o sociólogo tente equacionar o problema da classificação disciplinar de uma obra disciplinarmente inclassificável, pois elaborada fora do sistema escolar de delimitação científica - como atestam alguns excertos extraídos dos trechos eliminados pela Flama (ver. bloco 1; abaixo). Aproximação momentânea, desentendimento e desinteresse mútuo.

De outro lado, no espaço acadêmico, havia leitores de Marx, e citações diversas deste autor aparecem aqui e acolá. ${ }^{8}$ Entrementes, nem as citações de Marx dialogavam entre si, nem seus autores, por meio delas. Em suma, marxistas talvez houvesse; marxismo, não. A pequena população acadêmica dispunha de professores de esquerda, citadores de Marx, filiados ao Partido Comunista Brasileiro. Entrementes, não havia "marxismo" na FFCL-USP, enquanto posição teórica e política, repertório autoral comum e práticas de leitura legitimadas e compartilhadas, tampouco grupos ou indivíduos que encontrassem nesse atributo um "afastamento diferencial” no espaço. E é justamente por meio da criação da diferenças definidoras que os grupos passam a existir socialmente uns para os outros (BOURDIEU, 1967, p.122). Esta constatação vale também para Florestan Fernandes. O sociólogo incorporou Karl Marx ao repertório dos clássicos da Sociologia, tratando-o como um entre outros autores e não como $o$ autor que definisse sua posição na disciplina. ${ }^{9}$ Eis algo basilar no conteúdo da leitura proposta por ele - que se apresentará abaixo, em oposição a outra modalidade de leitura.

A modificação mais significativa no conjunto de leitores de Marx ocorre em 1958, um ano antes duas mencionadas publicações de Florestan Fernandes. Ao retornar de uma estadia acadêmica de dois anos na França, José Arthur Giannotti reuniu amigos para ler O capital de Karl Marx. Este filósofo havia estudado na Faculdade de Letras de Rennes, com Gilles-Gaston Granger e Victor Goldschmidt, seguido os cursos de Merleau-Ponty e Martial Guéroult, no Collège de France, e frequentado reuniões do grupo Socialismo ou Barbárie, convidado por Claude Lefort. Giannotti imaginou um grupo de estudos quando ainda estava na França, como atesta sua correspondência pessoal: "Adotei uma divisa: estudar os alemães modernos à moda francesa. Vamos ver o que vai dar. Afinal o nosso barbudo era alemão (judeu) e ainda vamos lê-lo no original." ${ }^{10}$ Além dele, frequentaram as reuniões deste "Seminário Marx" (como é conhecido), com graus 
variados de assiduidade: o filósofo Bento Prado Jr., os sociólogos Fernando Henrique Cardoso e Octavio Ianni, o historiador Fernando Novais, o sociólogo e crítico literário Roberto Schwarz, os economistas Paul Singer, Sebastião Advíncula da Cunha e Juarez Rubens Brandão Lopes - entre outros. ${ }^{11}$

Bloco 1. Excerto extraído da "Introdução" (1946), redigida para o texto Contribuição à crítica da Economia Política, publicado pela editora trotskista Flama, eliminado da versão que veio a público e exposto em 1959.

“(...) Do mesmo modo que nas ciências biológicas, o processo de crescimento é explicado por um mecanismo de desenvolvimento interno. Isso era importantíssimo para as ciências sociais, porque então se podia explicar a evolução social sem excluir o homem da História. (...). Esse novo critério explicativo do 'materialismo histórico' favorecia, por seu turno, o fortalecimento da noção de especificidade, o que era capital para as moderas ciências sociais particulares. De acordo com o que foi visto acima, em relação ao 'princípio de emergência', as leis científicas constituem tipos válidos somente dentro de dado domínio e com condições determinadas. A Física evidencia leis que só têm validade para o mundo físico; a Biologia, para os seres vivos; a Economia, para a vida associativa. Apesar de suas conexões e da inviabilidade de umas sem as outras, as suas leis não têm valor explicativo fora dos limites dos seus próprios objetos. A articulação das ciências no conjunto dos conhecimentos humanos não implica a absorção de umas pelas outras. Há algumas analogias com o Comtismo, menos quanto à compreensão e à explicação da realidade, é óbvio, que do ponto de vista das relações, da classificação e da interdependência das ciências. Exemplo disso é algo confusamente chamado do 'materialismo biológico' de Marx. Embora aceitando e utilizando as conclusões a que Darwin chegara, Marx evitou a aplicação pura e simples dos conceitos 'luta pela vida' e 'sobrevivência do mais forte' ao estudo da sociedade humana. (...) A eficiência de seus métodos e critérios explicativos, todavia, só pode ser devidamente apreciada pela análise dos resultados a que chegou, no estudo das sociedades capitalistas europeias do século XIX. Esses dados constituem a cúpula do edifício filosófico de Marx e Engels e geralmente são agrupados sob a rubrica 'materialismo histórico'. Todavia, há autores que pretendem designar a mesma coisa com outras expressões -'determinismo econômico'; 'interpretação econômica da História'; 'interpretação materialista da Historia'; da mesma forma, há desacordo quanto à natureza do conteúdo do 'materialismo histórico'. De fato, se reunirmos sob este item toda a teoria econômica, política e sociologia de Marx, podem-se caracterizar aí, contribuições parciais suas à Economia, à Sociologia, à Política, à Filosofia da História, à Filosofia Política, à Filosofia Social. Isso, todavia, tem um valor muito relativo, reduzindo-se, afinal de contas, a uma questão de perspectiva. (...) a discussão histórica da fundamentação lógica situa o 'materialismo histórico' como um método, que estaria para o 'materialismo dialético' como o método generalizador está para as ciências naturais e o método particularizador para a História. (...) Como esta pode ser devidamente apreciada (a filosofia marxista da história) no esquema que K. Marx fez para o prefácio desse livro, penso que seria inútil insistir sobre o assunto. Parece-me que é de maior interesse a análise de algumas críticas feitas a Marx, de fato ou pseudamente em nome da ciência. Não tenho em mente a sua defesa, com isto; o meu intuito é muito mais limitado e concreto: as ciências sociais alcançaram um estágio em que o desenvolvimento de sua obra parece tomar decisivamente outro rumo. Há, em todos os grandes centros de pesquisas e estudos sociais, um maior esforço de compreensão e uma nítida disposição inclusive para o aproveitamento efetivo de sua herança. Algumas notas, que contribuam para esclarecer ou pelo menos recolocar algumas questões são, portanto, oportunas." (FERNANDES, 1959, p. 318-322 -itálicos do autor, sublinhados meus)

Talvez um marxólogo rigoroso se incomode com uma súmula em que a atribuição de "dinâmica" como sinônimo de "dialética" ao pensamento de Marx dispense um raciocínio em termos de "contradição". Mas um durkheimiano não perde o ponto: é o paradigma da diferenciação e da morfologia que dá a direção da "porta de entrada" no sistema de pensamento de Marx. Nem poderia ser diferente - por tudo que tem sido exposto. Ademais, assinale-se que ao eliminar do texto de Florestan Fernandes precisamente esta última passagem destacada, que antecede a discussão a respeito das críticas endereçadas a Marx, o efeito de leitura construído pela editora Flama é precisamente o inverso do que pretende o sociólogo: defender (politicamente) Marx.

\section{ADVERSÁRIOS ALIADOS}

Naturalmente, Florestan Fernandes, tampouco qualquer catedrático para os quais estes seminaristas trabalhavam, foi convidado para o círculo de leituras de amigos de Giannotti. E, no entanto, ele se fez presente na ausência. Por um lado, pois seus dois principais auxiliares participavam dele - e, como todos, 
transportavam para o seminário as preocupações de sua disciplina de origem. Por outro lado, as práticas de trabalho coletivo racionalizado, adotadas por Giannotti na condução deste grupo, eram idênticas às da cadeira de Sociologia I, até então, únicas na instituição ainda marcada pelo ideal de trabalho individual e artesanal. Dito de modo simples: a reunião de competências específicas (lingüísticas e disciplinares), colocadas a serviço de um objetivo inicial comum (ler O Capital seguindo o método de "leitura estrutural do texto"), realizada de modo constante e disciplinado por anos seguidos, alinhando um repertório teórico obrigatório e um léxico conceitual compartilhados. A autoridade de Florestan, coordenando forças que se dispersariam sem ele, na cadeira de Sociologia I, corresponde à de Giannotti no Seminário. Portanto, os dois grupos são aliados face aos demais círculos e cátedras, para os quais esta modalidade de trabalho permanece estranha, e, embora a ela não reagissem nem passassem incólumes. A prática de novas formas de trabalho alterava o sentido das anteriores, remetia os praticantes delas às estratégias de conservação institucional, logo vistas como ultrapassadas (PULICI, 2008).

Aliados nas práticas e no interesse por Marx, adversários na maneira de ler e usar academicamente Marx. Gradativamente, colocam-se em disputa (a) pelo monopólio da leitura acadêmica legítima de Karl Marx e (b) pela legitimidade da introdução de autores marxistas na agenda de leituras obrigatória das Ciências Sociais. ${ }^{12}$ As posições similares junto aos grupos que constituíram e as afinidades de habitus entre Florestan Fernandes e José Arthur Giannotti permitem isolar a variável do pertencimento disciplinar e institucional para a compreensão dos usos sociais que a leitura de Marx suscitou. ${ }^{13}$ Trata-se de duas modalidades distintas de apropriação acadêmica da obra do mesmo autor. O filósofo-mentor do seminário encontra na leitura especializada de Marx e autores marxistas um "afastamento diferencial” no espaço da FFCL-USP, converte-o em atributo único de seu grupo face aos convivas, e alicerça nesta prática a autoridade do legislar a respeito do pertencimento e eliminação do marxismo daqueles aspirantes ao ingresso nele. Em contraste, o sociólogo pretende extrair a contribuição específica de Marx para a explicação sociológica - o que implica chancelar, sob devidas condições, seu uso e autorizar sua mescla com outras correntes teóricas. O bloco dos excertos a seguir é exemplar:

Bloco 2. Marx, modos disciplinares de usar: Filosofia e Sociologia.

"O método dialético oferece ao sujeito-investigador a possibilidade de ajustar-se intelectualmente à realidade social de modo a compreendê-la sob o tríplice aspecto em que ela pode apresentar-se, através de regularidades bem definidas: quanto às condições de formação de um dado sistema social; quanto às condições que intervêm na preservação desse sistema social; e quanto às condições que podem alterar a 'constituição íntima' do sistema social considerado e o sentido dessa alteração. Uma explicação dessa ordem pretende reter os fenômenos sociais em sua 'dinâmica real', aspirando interpretar, positivamente, a origem, a vigência e a transformação dos processos sociais. (...). Para atingir esse fim explicativo, precisa o especialista pôr em evidencia 'o caráter essencial' do fenômeno investigado. No caso, porém, a abstração do essencial segue um caminho bem diverso do que se evidencia na técnica de Weber ou na de Durkheim. O essencial, numa pesquisa de relações que operam causalmente, mas que se alteram continuamente em sua configuração e atividade, em determinados períodos de tempo, é naturalmente algo que permita explicar como e porque se produzem determinadas alterações da ordem social. Precisa ser forçosamente um fator construtivo e operativo, que contenha aquilo que Marx chamava de 'determinações comuns' (na linguagem sociológica moderna: as condições elementares e os processos sociais que se repetem ou recorrentes) e aquilo que ele entendia como as 'determinações particulares' (e que nós chamamos, atualmente, de condições sociais emergentes e processos sociais in flux), de maneira causal." (FERNANDES, 1959b, p. 115).

"É preciso que se reflita sobre a natureza e as implicações das soluções aos problemas da indução, contidas nas contribuições de Durkheim, Weber e Marx. É nosso pensamento que elas não traduzem meras inclinações ou preferências intelectuais de cada um desses autores. Ao contrário, parece de todo evidente que elas incidem sobre questões essenciais, que precisavam ser resolvidas, antes que os sociólogos pudessem se lançar em pistas novas, capazes de conduzir a maior integração sistemática da teoria sociológica. Não podemos discutir esta questão aqui. Contudo, podemos indicar que enxergamos em cada uma das orientações propostas uma possibilidade legítima de abordagem e solução dos problemas da explicação na sociologia. Aí está o ponto essencial da discussão. Os novos desenvolvimentos da teoria sociológica dependem, fundamentalmente, da capacidade que revelarmos na fusão 
dessas orientações, separadas no passado, mas naturalmente interdependentes e complementares. As diferenças mais salientes e desarmoniosas, que existem entre elas, não emanam propriamente da natureza da analise sociológica, pois derivam ou de influências de correntes filosóficas ou de maneiras peculiares de entender os limites e os fundamentos da explicação científica. Elas podem ser, portanto, superadas, desde que se encontrem os princípios que permitam unificar pela base a própria explicação sociológica.” (FERNANDES, 1959b, p. 121-122).

\begin{abstract}
“(os) erros de Celso Furtado, às vezes chocantes, são frutos de um pensamento que, ao tentar resolver questões em geral descuidadas pelas ciências conservadoras do homem (...) desafia seus instrumentos habituais (ao ocupar-se de problemas históricos, teve que) dar aos seus conceitos maior flexibilidade possível" (e "buscou socorro na dialética"). [Contudo, o Marx de Furtado corresponde ao da] "ciência acadêmica e, não pondo em xeque as interpretações do marxismo vulgar, termina em um impasse, ressuscitando a instransponível oposição entre a estática e a dinâmica sociais, enfim, por retroceder a um pensador tão tradicional como Durkheim (...) [erra também ao] "alinha(r) indiscriminadamente numa mesma posição todos aqueles que falam da totalidade qualquer que ela seja. (...) Embora o pretenda, sua concepção não é marxista”. (GIANNOTTI, 1965). (Trata-se de uma resenha do livro de Celso Furtado, Dialética do desenvolvimento).
\end{abstract}

Seria difícil não observar a modalidade acadêmica do esperneio antiacadêmico de Giannotti: o excerto acima pertence ao primeiro texto de uma série de outros em que ele e alguns seminaristas se especializariam. Trata-se de um exercício professoral de correção de termos, conceitos e leitura, construindo a (colocando-se à frente na) disputa pelo monopólio da leitura correta. Os trechos selecionados, de Florestan e Giannotti, são representativos de modalidades diversas de usos e de leituras especificamente universitárias, condicionadas pelo pertencimento disciplinar e pela fase de afirmação da autonomia das respectivas áreas de origem de seus autores. A Filosofia é atiçada pelo veredicto do que é ou não marxista, expresso na sentença de Giannotti dirigida a ninguém menos que Celso Furtado. A prática de "leitura estrutural do texto", o pertencimento à subdisciplina "Lógica", o exercício de jurisdição disciplinar que lhe é intrínseco e foi aprendido por Giannotti com Granger conferem a ele a certeza de uma autoridade intelectual capaz de se erguer acima da autoridade da consagração mundana do economista. Em contrapartida, a leitura de Florestan, animada pela contribuição que Marx tem a dar para a explicação sociológica (da formação, constituição e transformação sistêmica), não se orienta na direção da jurisdição de outras disciplinas, senão a sua própria, e, no interior dela, não exige a eliminação (mas pressupõe) Weber e Durkheim. Apenas subordina-a à natureza da pesquisa (sincrônica ou diacrônica), mantendo-se coerente com a "introdução" preparada para Flama (FERNANDES, 1959, p. 307).

A aparição de outro grupo de leitura d'O Capital, instada pela iniciativa de Giannotti, pelos desdobramentos concorrenciais entre professores e alunos na FFCL-USP, rearranjaria as posições dos grupos, originando outro eixo de alinhamento entre os seminaristas e Florestan Fernandes. Ambos passam a "envelhecidos" e "sacerdotais" face à emergência de uma inusitada posição mais jovem e "profética". ${ }^{14}$ Um grupo de estudos com membros mais jovens, igualmente especialistas em leitura d'O Capital, segundo método filosófico (aliados, portanto de Giannotti), igualmente preocupado com a peculiaridade do capitalismo no Brasil (aliados, portanto de Florestan) torna-se duplamente adversário. Por um lado, a leitura profissional pura sem contrapartida política é remetida ao polo inconsistente de um "marxismo de cátedra" (rivalizam, portanto com os seminaristas de Giannotti); por outro, as pesquisas empíricas e os surveys realizados pela equipe de Florestan Fernandes são alvo de deboche por sua "inconsciência teórica”. Apresenta-se a seguir os componentes e a produção deste novo círculo de leituras.

Por volta de 1963, Roberto Schwarz, ex-aluno do curso de Ciências Sociais da mesma instituição, voltava de uma estada nos EUA, e Ruy Fausto, ex-aluno do curso de Filosofia, voltava da França. Ambos tinham frequentado algumas reuniões do grupo de Giannotti e, como ele, reuniram amigos para ler O Capital. Também estavam atentos às pesquisas realizadas pela cadeira de Sociologia I, embora rechaçassem o espírito demasiado cientificista, em sua avaliação, do trabalho sociológico defendido por Florestan Fernandes. 
Animados por Schwarz e Ruy Fausto, tiveram variada frequência e adesão a este novo grupo: João Quartim de Moraes (filósofo), Paul Singer, Paulo Sandroni (economistas), Sergio Ferro (arquiteto), Lourdes Sola, Célia Quirino, Zé Chico, Emir Sader, Albertina Costa, Claudio Vouga, Francisco Weffort (cientistas sociais), Emília Viotti (historiadora), Beth Milan (médica). Os dois grupos estiveram em atividade concomitante, durante um curto período. Este círculo de leituras produziu três números de um periódico, Teoria e Prática. Particularmente, em 1967, no centenário da primeira edição d'O Capital, o terceiro número deste periódico documentou leituras divergentes da trajetória intelectual de Karl Marx.

Do ponto de vista dos leitores de Marx, a emergência deste grupo, altera a posição dos já existentes. E, do ponto de vista das cátedras, a Sociologia I, em 1963, não padecia mais da penúria de recursos anteriormente mencionada. Fernando Henrique Cardoso, já doutorado, com a tese Formação e desintegração da sociedade de castas. O negro na ordem escravocrata do Rio Grande do Sul, protagonista de seu "desafio teórico" a Florestan Fernandes e filiação ao "marxismo do seminário" (RODRIGUES, 2012), era àquela altura, diretor do Centro de Sociologia Industrial e do Trabalho (Cesit). Ele ofertava a jovens cientistas sociais oportunidades de trabalho (algumas remuneradas), cavadas junto a amigos da indústria e elites políticas paulistanas, para realizar surveys com empresários e trabalhadores. No Cesit e na cadeira de Sociologia I, a divisão do trabalho e dos poderes era unívoca e mutuamente exclusiva. Fernando Henrique Cardoso monopolizava o "poder temporal", angariando recursos, valendo-se de seu traquejo junto às elites da política universitária e do governo do Estado - sendo reconhecido prioritariamente por isso. Já Florestan Fernandes monopolizava o "poder espiritual", sendo reconhecido exclusivamente por seus talentos intelectuais (BOURDIEU, 1984). Desse modo, a autoria das investigações empíricas, típicas do Cesit, correspondia ao nome de Florestan Fernandes (ROMÃO, 2006). Muito embora alguns membros do segundo círculo de leitores trabalhassem para estas pesquisas, enquanto grupo, a revista Teoria e Prática era animada por um humor anti-institucional, típico de uma juventude ultraesquerda. ${ }^{15}$

Do ponto de vista político, diferentemente dos seminaristas de Giannotti e de Florestan Fernandes, eram militantes, alguns aderiram à luta armada, o número 4 da revista não foi editado pois ela foi perseguida pela policia política. Do ponto de vista disciplinar, liam Marx e autores marxistas (alguns já rotinizados e legitimados pelo seminário de Giannotti), acionando-os em registro antisociológico. Além disso, Teoria e Prática inclinava-se para a crítica cultural de obras cinematográficas e teatrais em cartaz ou recém-lançadas tentando tomar parte por meio delas, no debate político acalorado no intervalo entre os anos de 1964-1968. De maneira particular, a revista manifesta uma invariante estrutural do cenário acadêmico - a que opunha sociologia da cultura e sociologia das classes sociais e do desenvolvimento (PONTES, 1998). Entrementes, voltava seu esforço para unir esses polos, por meio de seu radicalismo político voltado ao exame da cultura na chave de um "materialismo dialético" - contra o risco do diletantismo de uma vertente e contra o risco do empirismo conformista da outra. O bloco 3 de excertos apresenta o sistema de oposições na emissão de juízos a respeito dos trabalhos dos concorrentes acima apresentados.

Bloco 3. Sistema de oposições

"O conflito entre o regime capitalista e a classe operária, por permanecer latente, por não se manifestar de forma consciente e aberta, ele se permite ignorar. Em suma, sua orientação empiricista denuncia como especulação enxergar as contradições latentes do regime, mas é extremamente tolerante nas suas especulações sobre a luta entre o 'Brasil moderno' e o 'arcaico'. (...) O marxismo se transformou em nacionalismo, a luta de classe se reduziu ao conflito industrial, a consciência proletária deu lugar ao populismo; Leôncio observa atentamente e se detém ante esses fatos. Quer abandonar as abordagens 'teleológicas' a partir de um 'modelo de 'classe operária' abstrata'. Mas ao se debruçar ante os fatos mais aparentes, elevou-se à categoria de absolutos. Desprezando a luta de classe que, mascarada embora, segue sendo o motor da História, não pode encarar o populismo como falsa consciência do proletariado, como uma ideologia com funções precisas. (...) Expliquemos: a análise concreta da consciência populista enquanto manifestação da consciência operária permite-nos aprofundar o conhecimento real da classe 
desde que não nos dobremos ante ela, desde que enxerguemos seus limites, suas funções e suas máscaras. Vale dizer, desde que procedamos a uma análise e não a sua reverência ante o fato examinado. Buscando uma classe operária 'concreta', Leôncio acaba preso à realidade oficial. O normal passa a ser classe operária 'desideologizda', o conflito sindical institucionalizado, as reformas sociais 'mais técnicas e menos emotivas'. (...) “Tal concepção - que afinal é predominante na sociologia moderna - tem o simples defeito de não apreender os fatores de mudança presente na realidade. (...) esse vício próprio de acadêmicos só pode ser perdoado dentro dos próprios círculos acadêmicos." (SADER, 1967, p. 75-77)

(o autor, Leôncio) "não vê a diferença” (Idem, p.76), "não se pergunta” (Idem, p. 75), "não percebe alcance” (Idem, p. 82), "vê sem ver" (Idem, p. 83), "não se eleva acima do nível descritivo” (Idem, p. 85), "suas perspectivas são monótonas e recorrentes: se tudo continuar como está, o resto também deverá se manter na mesma tendência" (Idem, p. 85); "a explicação de Leôncio é bem medíocre” (Idem, p. 86); "(o livro) tem as mesmas limitações populistas e desenvolvimentistas" (Idem, p. 86); “não pode enxergar (seus limites)” (Idem, p. 86).

A resenha de Eder Sader, para o livro de Leôncio Martins Rodrigues, Conflito Industrial e Sindicalismo no Brasil, ironicamente intitulada "Conflito industrial e luta de classes", participa do jogo de inversão da autoridade e hierarquia do espaço escolar acadêmico - princípio que estrutura os materiais escolhidos pelos "teóricos práticos" (grupo da Teoria e prática), não raro, os livros, ideias e autores favoritos de seus professores. ${ }^{16}$ Como Giannotti, e como todos os grupos de intelectuais de esquerda, valem-se do expediente de tornar o adversário "mais acadêmico" e, portanto, mais "comportado", "conformado", pouco/nada revolucionário.

Os excertos ilustram o sistema de oposições ordenando a crítica de Eder Sader a Leôncio Martins (e indiretamente à sociologia de Florestan Fernandes). De um lado, radicalismo/revolução/teoria; de outro, sociologia conformista/acadêmica/ da ordem vigente/empírica. Enquanto Leôncio Martins Rodrigues, assistente da Sociologia I e pesquisador do Cesit, neste livro, representativo dos estudos do centro, opõe-se ao marxismo de teoria sem empiria, Eder Sader, assistente da Sociologia II e participante do segundo círculo de leituras, situa-se contra a empiria sem a contradição que anima a teoria marxista. Se assim a oposição se configura no plano das tomadas de posição, ela é indissociável das posições (Sociologia I/dominante/ Leôncio x Sociologia II/dominada/Sader), no espaço científico, e, via de regra, os dominados se inclinam ao radicalismo ou à esquerda dos dominantes. ${ }^{17}$

Se, imediatamente após a constituição do seminário de Giannotti, as duas primeiras publicações de Florestan Fernandes sobre Marx vieram a lume, conta-se entre elas e as próximas, quase duas décadas (1959-1983). Vale dizer: no auge do radicalismo dos aspirantes a cientistas sociais, concorrentes mais jovens, o sociólogo estava envolvido com as operações para tentar salvar a si próprio e à sua cadeira, tanto da perseguição política e policial, quando do aparelhamento que seus rivais poderiam fazer das chances abertas pela reforma universitária, assim como atendendo a convites por todo o Brasil, para discuti-la (1964-1968). ${ }^{18}$ Novamente, a recuperação de sua trajetória intelectual e política auxiliam na compreensão tanto de um aparente abandono de Marx, quanto da modificação dos princípios de apropriação deste autor e dos conteúdos de sua leitura.

\section{O JOVEM MARX DE UM VELHO FLORESTAN?}

Florestan Fernandes foi aposentado compulsoriamente pelo regime civil-militar em 1969, com outros colegas da FFCL-USP. Abstraindo os detalhes factuais e interpessoais da dinâmica de aproveitamento da conjuntura política por grupos rivais em suas disputas internas de poder (ADUSP, 2004), pode-se afirmar, numa perspectiva macro histórica e de longa duração que o episódio consiste em mais um dos conflitos característicos das lutas dos agentes mobilizando forças heterônomas para fazer valer suas posições no espaço supostamente autônomo da produção de conhecimento (BOURDIEU, 1996, p. 248-sgts). Não sendo estáticos, o conflito entre os espaços político e científico/artístico são recorrentes - com saldo em geral 
favorável ao primeiro, seja em disciplinas dependentes do Estado, seja em países periféricos sem tradição científica forte (L'ESTOILE, 2002). Durante anos a fio, Florestan Fernandes amargou este desfecho, que marcou seu percurso ulterior. É preciso apresentá-lo.

Entre sua aposentadoria (1969) e o ingresso no Partido dos Trabalhadores (1986), ele passou três anos no Canadá e refez o percurso da interpretação da modernidade brasileira, tema central da equipe reunida por ele. Relendo sua própria obra e respondendo a antigos alunos e colaboradores da Sociologia I, brandiu, como tantos outros na mesma época, contra as teses dualistas que opunham Brasil moderno a arcaico, assinalando a maneira como estas duas dimensões sociais, econômicas e políticas correspondiam ao modo próprio do capitalismo periférico. Eis o élan de sua última obra de fôlego A revolução burguesa no Brasil, publicada em 1975. Nos anos 1970, suas atividades atrelaram-se a editoras. Destacam-se a coordenação da coleção Grandes Cientistas Sociais, junto à Editora Ática; bem como a direção da coleção Pensamento Socialista, junto à Editora Hucitec. Idealizou ainda as revistas Debate e Crítica e Contexto. Fez incursões esporádicas na docência, já sem os compromissos de juventude: na Pontifícia Universidade Católica (PUC-SP), em 1977-1978, ofereceu um curso sobre a revolução cubana e outro sobre a natureza sociológica da sociologia. ${ }^{19}$ Durante estes anos contribuiu com diversos periódicos - oficiais e "alternativos" - como Leia Livros, Voz da Unidade, Nova Escrita Ensaio, Opinião, Movimento, Senhor, Senzala, Folhetim (SEREZA, 2005, p. 120-sgts). A partir de 1983, escreve periodicamente na Folha de S. Paulo. Foi eleito duas vezes como deputado federal, pelo Partido dos Trabalhadores (PT) - ao qual se filiou em 1986, com o intuito precípuo de participar da elaboração da Constituinte. Nela, integrou a Subcomissão de Educação, cultura e esportes; apresentou 93 emendas; atuou com o antigo aluno, Fernando Henrique Cardoso, então líder do Partido do Movimento Democrático Brasileiro (PMDB) no Senado. Quem o acompanhasse na grande imprensa nesses anos notaria o esforço heroico de tentar mobilizar seus esquemas interpretativos macro históricos para a explicação da conjuntura política. ${ }^{20}$

O centenário da morte de Karl Marx foi repleto de edições que o celebravam. Os leitores dos círculos mencionados anteriormente tomaram a palavra e documentaram as condicionantes sociais, disciplinares e institucionais de seus percursos incidindo sobre as leituras de Marx que passaram a defender. Em 1983, os expoentes destes círculos, contudo, ocupavam posições diversas e não encontravam mais uns nos outros os interlocutores de referência. Esta configuração era resultado da dispersão de seus rumos, condicionada pela direção de cada trajetória face o leque de alternativas possíveis em 1969. Assinale-se que o percurso de Florestan Fernandes em contraste com os demais - é, novamente, de exceção. Ir para o Canadá não foi a escolha preferencial do conjunto que, grosso modo, seguiu para Chile, França, Inglaterra e/ou Estados Unidos da América. ${ }^{21}$

A ditadura civil-militar perseguiu produtores simbólicos (intelectuais e artistas) e censurou produtos de sua atividade (aulas, livros, peças, filmes, músicas). Contudo, não impediu a existência da indústria cultural (favorecendo a ampliação do mercado de trabalho de artistas em geral) e tampouco ao sistema de pós-graduação e aos centros de pesquisa social (favorecendo o abrigo de cientistas sociais destituídos dos postos de ensino). Ao contrário, objetivamente, estimulou-os; embora tenha colocado freios seletivos aos conteúdos deles (ORTIZ, 2001). Uma nova morfologia institucional serviu de suporte à ciência social produzida no Brasil, resultante de financiamentos estatais e mecenato de fundações estrangeiras impactando os padrões de colaboração e concorrência entre as disciplinas (GARCIA Jr., 2009) levando ao estabelecimento de pelo menos três instituições - o Centro Brasileiro de Análise e Pesquisa (em São Paulo, multidisciplinar); o programa de pós-graduação em Antropologia do Museu Nacional (Rio de Janeiro); o de Ciência Política no Instituto Universitário de Pesquisa do Estado do Rio de Janeiro. 
A bibliografia ainda não apresenta um balanço de conjunto a respeito da posição do marxismo no cenário das Ciências Sociais nesta fase. Entretanto, o exame das trajetórias pertinentes autoriza afirmar que há três processos concomitantes que adquirem feições próprias segundo as variantes disciplinares e geracionais: engajamento em iniciativas culturais contra o regime, justificada em nome da profissão intelectual e da ciência social; segmentação e multiplicação dos grupos marxistas (gramscinianos, althusserianos, lukacianos), motivadas por percurso de conversão do campo político para o campo acadêmico. A despeito das ressalvas, uma constatação pode ser feita com segurança: os autores que passam a organizar os grupos (Gramsci, Althusser, Lukács) pendem para o polo menos partidário do marxismo - ou, para usar um termo corrente, a fim de facilitar o andamento desta exposição: são autores que correspondem ao assim chamado "marxismo ocidental".22 Já Florestan Fernandes, encarnação do modelo de scholar possível na acanhada FFCL-USP dos anos 1950, passa crescentemente a valorizar os autores do assim chamado "marxismo oriental". A seleção de autores marxistas para a coleção Grandes Cientistas Sociais da editora Ática sustenta esta assertiva: Lenin, Stalin, Che Guevara emparelham-se com Lucien Febvre (historiador). O texto de maior escopo sobre Karl Marx (e Friedrich Engels - cuja valorização, como todo "marxista oriental", Florestan não cessa de defender) é publicado precisamente nesta coleção.

Considerando as leituras conflitivas, acima apresentadas, a de Florestan Fernandes, apresenta uma reviravolta correspondente à reviravolta de sua posição no espaço das ciências sociais e da política. No centenário de morte de Karl Marx, do ponto de vista político, ele não era um desertor do trotskismo (como no final dos anos 1940), tampouco negociava recursos junto ao governador, angariando rivais poderosos bem situados nos poderes da instituição em que trabalhava (como entre 1954-1960). Do ponto de vista da trajetória científica, ele não era um jovem aspirante a cientista social (como no primeiro momento) e tampouco um catedrático-regente, algo atingido pela iniciativa de alguns de seus assistentes que se puseram a desafiá-lo (como no segundo). Relativamente livre dos constrangimentos materiais de sua juventude e das obrigações institucionais de sua maturidade, gozando de um prestígio de integridade intelectual e política que outrora pressupunha distância da política partidária e panfletária, o velho Florestan elaborou um Marx igualmente livre daquele regime anterior de (suas) obrigações. O "seu Marx" deste ponto da trajetória é mobilizado para colocar contra a parede as instituições científicas, a sociologia acadêmica e os intelectuais, e defender a revolução como critério de autonomia científica, atestada pela militância junto à classe revolucionária. Se os trechos abaixo tivessem suas legendas suprimidas, poder-se-ia supor que saíram das páginas de antigos adversários animados pelo humor anti-institucional da revista Teoria e Prática. Sublinhe-se o argumento: este Marx é relativamente livre das coerções institucionais incorporadas do estágio anterior da trajetória de Florestan, que balizava as questões endereçadas aos textos. Mas não é destituído de relações condicionantes. Ao contrário, elas obedecem inteiramente ao princípio que situa sucessivamente o Florestan Fernandes em posições de exceção - acima denominada de "estranho no ninho". A tomada de posição mais estritamente lógica tem contrapartida socio-lógica. Enquanto o conjunto de seus pares segue para exílios no Chile, França, Inglaterra e/ou Estados Unidos da América - ele, exceção no conjunto, segue para o Canadá. Enquanto os que permanecem no Brasil, associam-se seja no Cebrap, seja em outros centros - ele permanece ensimesmado, fazendo intervenções esporádicas crescentemente politizadas, eivadas do vocabulário "revolucionário" (como assinalou-se acima), ao passo que seus pares, nestes centros, gradativamente adotam o léxico da "democracia". Enquanto os marxistas convertidos do âmbito partidário para o acadêmico são difusores do marxismo ocidental no Brasil, ele ambiciona por em circulação e debate, os autores do marxismo oriental.

Bloco final: Marxismo oriental

"A universidade e a especialização criaram um processo profundo e persistente de fragmentação do trabalho de investigação em todas as ciências. Esse processo, porém, é mais intenso e devastador nas ciências sociais. O sociólogo, o historiador, o antropólogo, o cientista político, o psicólogo, mesmo quando marxista, sucumbem a 
essa tendência. Marx e Engels trabalharam numa direção oposta, defendendo uma concepção unitária de ciência representando a história como uma ciência de síntese. Se lidei com textos de K. Marx e F. Engels desde o início de minha carreira, nem por isso escapei à especialização dominante. É como sociólogo, portanto que me lanço a esta tarefa”. (FERNANDES, 1983, p.10)

"Infelizmente, os intelectuais - mais precisamente os acadêmicos - marxistas perderam muito tempo em repetições de uma sistematização do marxismo que é estéril para o enriquecimento daquela obra científica. Misturando os papéis acadêmicos com as tarefas de intelectuais de partido, deixaram à margem o que era essencial para a ciência (1); encetar e multiplicar as investigações originais que usassem menos palavras como 'marxismo', 'materialismo dialético', 'contradição', etc., (ou certas palavras rebarbativas, que não se encontram em Marx), e revelassem mais o verdadeiro espírito de análise e de explicação causal subjacentes a $O$ capital. K. Marx e F. Engels produziram fora do mundo acadêmico e contra a corrente. É uma irrisão que eles se convertam -principalmente em nome do marxismo e da dialética materialista - em meio de ganhar prestígio intelectual e de entreter modas filosóficas”. (...) "Portanto, também no plano do método aparece claramente o que significa 'aliar-se ativamente' ou 'fazer parte permanentemente’ do movimento operário. A burguesia engendrou um esquema liberal de ciência aplicada, pela qual afastou, na aparência, a ciência da dominação de classe. O proletariado não poderia fazer a mesma coisa, como vítima que era dessa dominação e, mais ainda, como sujeito determinado que era de uma revolução para acabar com a dominação de classe e com as próprias classes sociais. Por aí se desvenda a natureza e o significado da concepção materialista e dialética da história, instrumento claro, aberto, direto da consciência social e da atividade política revolucionárias das classes trabalhadoras”. (FERNANDES, 1983, p. 14-16)

\footnotetext{
"Sem dúvida, a 'posição radical' de ambos oferece um bom ângulo para avaliar o modo rápido, coerente e íntegro segundo o qual eles se confrontaram com a verdade histórica de sua consciência, do mundo em que viviam e de sua época. No entanto, a revolução de que se tornaram porta-vozes e militantes não brotou das formas intelectuais da consciência - ela emergiu do próprio curso da história. Se o radicalismo de ambos lhes permitira compreender essa revolução no seu íntimo e incorporá-la a seu modo profundo de ser, de pensar e de agir, eles não inventaram nem a criaram. Como eles testemunham de maneira eloquente, serviram-na. Serviram-na com todo o ardor e sem desfalecimentos - mesmo e principalmente quando a sorte se mostrou por demais severa e os fatos pareciam contrariar todas as esperanças revolucionárias." (...). "O cientista que se coloca fora da ordem estabelecida por causa de sua vinculação com o proletariado também fica acima das deformações que ela impõe à pesquisa científica. (...) Marx não se exprime nesse prefácio como um 'filho do Povo'. A sua linguagem é serena, sintética e severa. Tal como convinha a alguém que enunciava a teoria da revolução social inerente à consciência de classe e ao futuro político do proletariado, dos quais participava intimamente - como militante proletário, como cientista social e como estrategista do movimento socialista revolucionário. O que interessa, aqui, é que o centro de gravidade de uma posição de classe por ser a posição de uma classe revolucionária em ascensão histórica, assegurava ao cientista social uma extrema autonomia. Ele não precisava curvar-se às deformações, porque uma classe social revolucionaria não pode travar e vencer seus combates freando a contribuição da ciência ao alargamento e ao aprofundamento de sua consciência histórica e de sua capacidade de ação coletiva histórica”. (FERNANDES, 1983, p. 18-20)
}

Naturalmente, a posição junto ao novo cenário de referência orienta a leitura de Florestan Fernandes. Obviamente, entre ela e as leituras anteriores, há linhas de continuidade - sendo a principal delas, qualificar Marx como o pensador da mudança, a ser mobilizado na análise e na prática política da transformação social global. ${ }^{23} \mathrm{E}$, no entanto, há duas dimensões que Florestan scholar leitor de Marx não introduzia em seus argumentos: a revolução e a unidade entre prática e teoria entendidas como parte específica do método científico. A posição da revolução no argumento pareceria corresponder à posição de Florestan Fernandes junto ao sistema institucional. Sem ela como hipótese, não há autonomia científica - posto que o cientista está preso a amarras da ordem, limitado, incapaz. Com ela, resta ao cientista pôr-se fora da instituição em que se pratica a ciência, como ele próprio.

\section{CONSIDERAÇÕES FINAIS}

Este trabalho parte da ideia simples segundo a qual as obras dos autores comportam numerosas leituras. Não poderia ser diferente com Karl Marx. Daí decorre o esforço de entender as condicionantes das múltiplas leituras que uma obra comporta - não se contentando em afirmar que tal multiplicidade tenha origem na "riqueza" da obra, tipo de decreto do bom gosto douto, mas que em nada instiga a pesquisa. $\mathrm{O}$ conjunto 
(de livros, ideias, conceitos, controvérsias) que conforma o patrimônio intelectual do marxismo emergiu fora do espaço das instituições científicas, sendo gradativa e conflitivamente incorporado a elas - característica, aliás, que não lhe é exclusiva, podendo ser observada também em outras linhagens, como a psicanálise, por exemplo (ELIAS, 1982). Este processo não se deu de modo natural por obra de um valor intrínseco da obra de Marx e dos marxistas. Estando de acordo a respeito disso, interessa caracterizar, analisar e explicar o trabalho de agentes específicos em cenários particulares que agiram nesta direção. ${ }^{24}$ Como mostrou Matonti (2005), seria um ledo engano supor que este projeto se realiza ignorando o marxismo produzido nos espaços não-científicos - interessa, ao contrário, prioritariamente, analisar as relações de troca assimétrica entre os espaços de leitura, ensino, produção e difusão de livros, ideias e conceitos desta tradição. É como parte deste escopo mais amplo que o presente trabalho procurou situar artífices da introdução e rotinização da leitura de Marx em seus espaços profissionais, disciplinares, institucionais e também, dentro dos limites possíveis, localizar estes espaços, no campo político. Florestan Fernandes esteve no epicentro deste processo, do mesmo modo que esteve no de outro - o da institucionalização da moderna sociologia em São Paulo. Ao ocupar-se de sua trajetória, tinha-se em mira estes problemas de pesquisa - daí um uso criterioso de seus comentadores. Espera-se, com isso, ter trazido novos nexos de sentido para o a compreensão do marxismo (senão brasileiro, paulistano), em suas vertentes "partidária" e "científica" quanto da posição de Florestan Fernandes no interior dele.

\section{NOTAS}

1. Este trabalho foi desenvolvido com auxílio de uma Bolsa de Pós-Doutoramento da FAPESP.

2. O trabalho exemplar para análise sistemática das relações entre sistema partidário/sistema de ensino - base para a explicação das tomadas de posição política dos intelectuais - é: MATONTI, 2005. Valeria ressaltar que esta pesquisa, ao destacar as dimensões de negociação entre direção e militância intelectual do Partido Comunista Francês (PCF), nos textos publicados pela Nouvelle Critique, reduziu a pó interpretações que tratavam o PCF como uma de "instituição total" e seus quadros como "intelectuais domesticados": visão direitista difundida em vulgatas sem fundamento empírico que não sejam fatos alinhavados segundo o gosto desta mesma visão e das facilidades a que se entrega.

3. Esta observação visa esclarecer que a leitura das obras realizadas por trabalhos bourdiesianos não se orienta pelo que é conhecido por "leitura estrutural do texto", que tem por mentor principal o filósofo Martial Guéroult e por plataforma metodológica difundida entre os brasileiros, o trabalho de Victor Goldschmidt. (GOLDSCHMIDT, 1963). Externos ao âmbito da Filosofia, os historiadores da vida intelectual põem-se em busca justamente dos nexos entre tempo histórico e tempo lógico dos autores/obras que investigam - embora discordem a respeito de como estabelecê-lo.

4. Os termos, e o encadeamento dos mesmos, foram retirados de: D'INCAO, 1987. Trata-se da reunião dos textos dos participantes da primeira grande homenagem recebida por Florestan Fernandes, ainda em vida, na Unesp/campus Marília. Sendo criadas por ex-alunos, amigos e admiradores, as motivações na base das mesmas só poderiam ser alheias a uma análise objetivante. Esclareça-se, correndo o risco de ser pedagógico demais: esta tomada de distância não implica julgamento positivo ou negativo das classificações e agenda de leitura por elas controlada. Trata-se tão somente de levar a termo o compromisso analítico adotado neste trabalho, o que significa estar impedido de entrar no debate ignorando a "história das categorias de pensamento" (Idem, p. 19) por meio das quais ele se instaurou. Tive a grata oportunidade de participar de cinco eventos de celebração pelos vinte anos de falecimento de Florestan Fernandes (dois na capital paulista e três no interior do estado) e pude constatar a longevidade destas categorias de raciocínio.

5. E o mesmo se verificaria ao cotejar com o recrutamento do restante do leque de alternativas partidárias, considerando as frações da esquerda (posto que nas demais, Partido Republicano Paulista ou Partido Democrático, a fronteira social do recrutamento seria mais óbvia). Para o polo comunista, ver RODRIGUES, 1981. Para a esquerda não comunista, ver HECKER, 1998. 
6. Este é um elemento desta coerência/lógica da edição, não o único.

7. Emprego o termo para designar especialistas na obra de Karl Marx, sem qualquer juízo de valor. A assertiva baseiase no contraste entre a bibliografia de apoio encontrada neste texto e na bibliografia de apoio encontrada em textos posteriores de Florestan Fernandes sobre Marx. Naturalmente, não se ignora que o mercado de autores disponíveis para leitura e citação sofreu alterações de monta entre 1946 e 1983. Ainda assim, a observação é válida, pois a escassez de marxólogos em 1946 não justificaria a ausência deles no texto.

8. A afirmação baseia-se na leitura dos Anuários da FFCL-USP, cotejada com os periódicos em que os professores publicavam. Até onde a pesquisa alcançou, entre os pares mais próximos, o texto de Florestan Fernandes é citado, na edição da Flama, por Lourival Gomes Machado (MACHADO, 1948).

9. Por isso, Karl Marx corresponde ao item “3”, antecedido por Durkheim e Weber, na apresentação das "As soluções fundamentais dos problemas da indução em Sociologia” (FERNANDES, 1959).

10. Correspondência de GIANNOTTI para João Cruz Costa. Paris, 28/10/1957. Acervo Cruz Costa. Biblioteca da Faculdade de Filosofia, Letras e Ciências Humanas. Universidade de São Paulo.

11. Este seminário poderia ser tratado como uma experiência de alinhamento de habitus. As teses que se originaram do diálogo interno constituído entre os seus membros, se deslocadas desta interlocução, e analisadas exclusivamente à luz de disciplinas, temas, famílias intelectuais imaginárias, dão origem a uma enxurrada de filiações que correspondem ao repertório com que opera o comentador. Em geral, alheias ao projeto intelectual dos próprios seminaristas. A reconstituição a seguir baseia-se na tese que defendi a respeito desse grupo RODRIGUES, 2012.

12. Em função de limitações de espaço, trata-se apenas da disputa em torno de (a).

13. O ethos do trabalho em oposição ao ethos do intelectual diletante, na base das tomadas de posição pelo trabalho regrado profissionalizado alicerçado em competências adquiridas em oposição ao ensaísmo do gênio naturalmente competente, remete a um principio estrutural invariante nos cenários de diversificação da origem social dos praticantes dos domínios do conhecimento (LEPENIES, 1996). Nos casos em questão, também são homologas as posições ocupadas por Giannotti e Florestan junto à Filosofia e Sociologia - ambos situam-se contra os ensaístas/aristocratas e defendem a disciplina do trabalho para aquisição de competências específicas da área (ARANTES, 1994).

14. "Sacerdotes", "profetas" e "magos” são três tipos correspondentes a três demandas de mensagem e serviços religiosos por parte da clientela, disputada por eles. Segue-se o esquema proposto por Pierre Bourdieu, que recupera a sociologia da religião de Weber, para análise das estruturas invariantes dos sistemas simbólicos (BOURDIEU, 2003).

15. Levando às últimas consequências a proposta analítica adotada, seria o caso de situar e analisar Teoria e Prática no espaço das revistas estudantis, voltadas à arte, política e teoria social, com as quais se constituía um espaço próprio de interesses dos produtores/consumidores de vanguardismo em termos de costumes e cultura. Seriam constitutivas deste espaço: (a), sua homóloga, no Rio de Janeiro (e com a qual alguns membros colaboravam, e da qual eram todos leitores) - a Revista da Civilização Brasileira (guardadas as devidas proporções de acanhamento paulista e densidade carioca em termos de produção e consumo cultural àquela altura); (b) as paulistanas (com as quais alguns colaboravam, por amizade pessoal aos editores) aParte, Revisão. É pela economia deste texto que não se desenvolverá a demonstração deste espaço, mas obviamente o que se afirma não o ignora.

16. A disputa filosófica, com contrapartida nesse sistema de oposições, opôs o professor de lógica, recém livre-docente, José Arthur Giannotti, a seu ex-aluno João Quartim de Moraes (Respectivamente: "Contra Althusser”; "Sobre 'Origens da dialética do trabalho” - ambos em: Teoria e prática, n. 3). Exemplar, ao lado destes, do princípio de inversão das autoridades estabelecidas pela hierarquia dos papeis institucionais, professor/aluno é o texto de Lourdes Sola/aluna sobre Durkheim/professor Florestan. Diga-se de passagem: na biblioteca pessoal de Florestan Fernandes (situada na Universidade Federal de São Carlos) é o único texto do periódico lido e marcado com grifos (SOLA, 1966). 
17. Convém sublinhar os termos da formulação. A rigor não há, entre os agentes da configuração que se caracteriza acima, posições de direita, mas posições à esquerda uma das outras. Este é o atiçador da disputa: o expoente de radicalismo político e possibilidade de remeter o adversário intelectual à posição menor/menos radical/revolucionária - lógica de uma concorrência que só se desenrola entre intelectuais de esquerda (BRUN, 2014).

18. O que se averigua no "mapa" dos artigos publicados por FERNANDES, 1975. Entre 1962 (fim da Campanha pela Escola Pública e anúncio da reforma universitária) e 1968 (emergência das paritárias - que ambicionavam conduzir a reforma universitária e foram derrotadas), o sociólogo acelera as titulações de sua equipe na esperança de blindar os postos em abertura, dela oriundos. A análise do ritmo das titulações evidencia isso (ARRUDA, 1995).

19. Este curso não entra na seriação dos textos aqui apresentados, pois se selecionou apenas o que ele escreveu tendo por pretexto Karl Marx. Este curso mereceria atenção caso o tema em apresentação fosse deslocado para a "tradição marxista”, pensada, aí, nos nexos com as tradições clássicas da sociologia.

20. Este empenho ficou documentado nos livros: Apontamentos sobre a teoria do autoritarismo. São Paulo: HUCITEC, 1980; Brasil em compasso de espera. São Paulo: HUCITEC, 1980. (Coleção Pensamento Socialista); Movimento socialista e partidos políticos. São Paulo: HUCITEC, 1980; A ditadura em questão. São Paulo, T. A. Queiroz, 1982; Que tipo de República? São Paulo: Brasiliense, 1986; Nova República? Rio de Janeiro: Zahar, 1986. (Coleção Brasil: os anos do autoritarismo); A constituição inacabada: vias históricas e significado. São Paulo: Estação Liberdade, 1989; Pensamento e Ação: o PT e os rumos do socialismo. São Paulo: Brasiliense, 1989.

21. Obviamente, não interessa ao argumento mencionar o rumo de cada uma das trajetórias dos componentes dos três grupos (Sociologia I, Seminário, Teoria e prática). Por isso, nesta etapa da demonstração, opta-se por voltar o foco à posição de Florestan Fernandes em relação ao novo cenário institucional das Ciências Sociais e ao marxismo praticado em seu interior - duas fontes principais da interlocução implícita e explícita de seus textos nos anos que sucedem sua aposentadoria compulsória e antecedem seu ingresso no PT. O exame completo requerido pelo que se pretende - para manter-se em equilíbrio com a caracterização dos espaços que se empenhou em fazer para o período anterior - deveria investigar também: (a) a profissionalização dos quadros políticos e (b) as características do marxismo no campo político. Assumimos as conclusões de algumas pesquisas para dar prosseguimento a esta apresentação. Quanto a (a) - a precária renovação das elites políticas no período do regime militar viabilizou o ingresso de numerosos intelectuais na esfera política, abandonando a científica. O caso exemplar é o de Fernando Henrique Cardoso (GARCIA Jr., 2004). Quanto a (b) - por um lado, as forças de esquerda estão fisicamente dizimadas ou exiladas desde meados dos anos 1970; e, por outro, o marxismo praticado nos partidos sofrerá de uma perda de respeitabilidade, pelo trabalho de detração levado a cabo pelos próprios comunistas, convertidos ao campo científico. É exemplar disso o livro: (KONDER, 1988). Para o ponto que nos interessa: não é ao marxismo de partido que se dirige Florestan Fernandes; muito embora não sejam poucos os antigos comunistas que se dirigirão crescentemente para o debate com o marxismo praticado nas universidades.

\section{Ver. nota supra.}

23. Não há espaço no presente trabalho para se discutir a obra de Karl Marx classificada em outras "disciplinas" nesta coleção. Obviamente, não se ignora que há uma coletânea em Economia e outra em Sociologia, cujas introduções, redigidas por Paul Singer e Octavio Ianni não passam incólumes à história da configuração dos leitores universitários, colaboradores e concorrentes, acima referida. Não por acaso: Giannotti deveria ter feito a "Introdução" para o volume de História. Por ele não ter feito, Florestan advoga para si a tarefa. Por todo o exposto acima, está longe de ser uma coincidência que Florestan a tenha solicitado ao filósofo - mas na falta de outras informações que esclareçam o histórico do convite/recusa, pensamos ser melhor não especular aleatoriamente.

24. Esta incorporação, sem as preocupações que aqui se manifestam, tem sido denominada por praticamente toda a bibliografia especializada no assunto, de "marxismo ocidental" (elaborada pela primeira vez por PONTY (2006) e revigorada por ANDERSON (2004). Vale dizer, do mesmo modo que este último deu origem a uma biblioteca a respeito do "marxismo ocidental", atualmente, conta-se com outra biblioteca, discutindo a validade deste conceito. 
O presente trabalho entende que extraindo o tom acusatório do termo (marxismo ocidental, de cátedra - em suma, que dispensa envolvimento com a prática político-partidária), resta-lhe o caráter descritivo, e não analítico. Daí optar por caminhos de pesquisa diversos.

\section{REFERÊNCIAS BIBLIOGRÁFICAS}

ADUSP. 2004. O controle ideológico na USP: 1964-1978. [1978] São Paulo: Adusp.

ANDERSON, P. 2004. Considerações sobre o marxismo ocidental. São Paulo: Boitempo.

ARANTES, P. 1994. Um departamento francês no ultramar: estudos sobre a formação da cultura filosófica uspiana. Rio de Janeiro: Paz e Terra.

ARRUDA, M. A. N. 1995. "A Sociologia no Brasil: Florestan Fernandes e a 'escola paulista'. In. MICELI, S. (org.). História das Ciências Sociais no Brasil. Vol 2. São Paulo: Sumaré.

2001. Metrópole e cultura. Bauru: Edusc.

BASTOS, E. et al. 2006. Conversas com sociólogos brasileiros. São Paulo: Editora 34.

BOSCHETTI, A. 1985. Sartre et Les temps modernes. Une entreprise intellectuelle. Paris: Edititons Minuit.

BRUN, E. 2014. Les situationnistes. Une avant-garde totale. Paris: CNRS Éditions.

BOURDIEU, P. 2001. Meditações pascalianas. Rio de Janeiro: Bertrand Brasil.

1967. “Campo intelectual e projeto criador". In. POUILLON, J. Problemas do estruturalismo. Rio de Janeiro: Zahar.

1984. Homo academicus. Paris: Minuit.

1986. "Lillusion biographique". In. Actes de la recherche em sciences sociales, n. 1.

1996. As regras da arte. Trad. port. Lisboa: Editorial Presença.

2003. "Gênese e estrutura do campo religioso". In. Economia das trocas simbólicas. São Paulo:

Perspectiva.

CANDIDO, A. 1996. Lembrando Florestan Fernandes. São Paulo: s.n.

$\mathrm{D}>\mathrm{INCAO}, \mathrm{M}$. A. (org.). 1987. O saber militante. Ensaios sobre Florestan Fernandes. São Paulo: Unesp.

ELIAS, N. 1982. "Scientific establishments". In.: ELIAS, N et. All. (orgs.). Scientific Establishments and Hierarquies. Dordrecht: D. Rieder.

FERNANDES, F. 1959. Ensaios de sociologia geral e aplicada. São Paulo: Livraria Pioneira. 1959b. Fundamentos empíricos da explicação sociológica. São Paulo: Companhia Editora Nacional. 
1975. A universidade brasileira: reforma ou revolução? São Paulo: Alfa-Omega.

1980. Apontamentos sobre a teoria do autoritarismo. São Paulo, HUCITEC.

1980. Brasil em compasso de espera. São Paulo, HUCITEC.

1980. Movimento socialista e partidos políticos. São Paulo, HUCITEC.

1982. A ditadura em questão. São Paulo, T. A. Queiroz.

1983. “Introdução”. In. Marx/Engels: História. São Paulo: Ática.

1986. Que tipo de República? São Paulo, Brasiliense.

1986. Nova República? Rio de Janeiro, Zahar.

1989. A constituição inacabada: vias históricas e significado. São Paulo, Estação Liberdade.

1989. Pensamento e Ação: o PT e os rumos do socialismo. São Paulo, Brasiliense.

FERNANDES, H. 2005. "Florestan Fernandes, Universidade e MST". Caros amigos, n. 96.

GARCIA, S. G. 2002. Destino ímpar. Sobre a formação de Florestan Fernandes. São Paulo: Editora 34.

GIANNOTTI, J. A. 28/10/1957. Correspondência de José Arthur Giannotti para João Cruz Costa. Paris. Acervo Cruz Costa. Biblioteca da Faculdade de Filosofia, Letras e Ciências Humanas. Universidade de São Paulo.

1960. “Notas metodológicas para leitura d'O Capital”. Revista Brasiliense, n. 29, maio-junho.

1965. "A propósito de uma incursão na dialética”. Revista Civilização Brasileira, n. 3, julho.

1967. "Contra Althusser". Teoria e prática, n. 3.

GARCIA Jr. A. 2004. «Une noblesse républicaine. Fernando Henrique Cardoso et la sociologie au Brésil ». In. SAPIRO, G et. al. (orgs). Pour une histoire des sciences sociales. Paris : Fayard.

2009. “Études internationales et renouveau des modes de pensée et des institutions politiques: le cas du Brésil ». In. Cahiers de la recherche sur l'éducation et les savoirs, v. 2.

GOLDSCHMIDT, V. 1963. “Tempo histórico e tempo lógico na interpretação dos sistemas filosóficos”. In. A religião de Platão. São Paulo: Difel.

GOUARNÉ, I. 2013. L'introduction du marxisme en France. Philosoviétisme et sciences humaines (1920-1939). Rennes : Presses Universitaires de Rennes.

HECKER, A. 1998. Socialismo sociável. História da esquerda democrática em São Paulo. (1945-1965) São Paulo: Ed. Unesp. 
HOBSBAWM, E. 1983. História do marxismo, v. I. O marxismo no tempo de Marx. Rio de Janeiro: Paz e Terra.

KEINERT, F. 2011. Cientistas sociais entre ciência e política (Brasil, 1968-1985). Doutorado, FFLCH-USP.

KONDER, L. 1988. A derrota da dialética. Rio de Janeiro: Campus.

LEPENIES, W. 1996. As três culturas. São Paulo: Edusp.

L’ESTOILE, B. 2002. "Ciência do homem e dominação racional: saber etnológico e política indígena na África colonial francesa”. In. L’ESTOILE, B. et. all. Antropologia, Impérios e Estados Nacionais. RJ: Relumé Dumará.

LIMONGI, F. 2001. "Mentores e clientelas da Universidade de São Paulo". In. MICELI, S. (org.). História das Ciências Sociais no Brasil, v. 1. São Paulo: Sumaré.

MACHADO, L. G. 1948. “Sobre o conceito de realidade social na obra de Karl Marx”. In. Sociologia, n. 2-3.

MARX, K; ENGELS, F. 2007. A ideologia alemã. São Paulo: Boitempo.

MATONTI, F.; SAPIRO, G. 2009. "L'engagement des intellectuels: nouvelles perspectives". Actes de la recherche en sciences sociales, n. 176-177.

MATONTI, F. 2005. Intellectuels communistes. Essai sur l'óbéissance politique. La Nouvelle Critique (19671980). Paris: La Découverte.

MERLEAU-PONTY, M. 2006 (1955). As aventuras da dialética. São Paulo: Martins Fontes.

MICELI, S. (org.). 1993. A Fundação Ford no Brasil. São Paulo: Sumaré/Fapesp.

MORAES, J. G.; REGO, J. M. 2000. Conversas com historiadores brasileiros. São Paulo: Ed. 34.

MORAES, J. Q. 1967. “Sobre ‘Origens da dialética do trabalho”. Teoria e prática, n. 3.

NOBRE, M.; REGO, J. M. 2000. Conversas com filósofos brasileiros. São Paulo: Ed.34.

PINHEIRO FILHO, F. 2009. A. The renovation: aspects of Pierre Bourdieu's reception in Brazil. Sociologica (Bologna), v.1.

ORTIZ, Renato. 2001. A moderna tradição brasileira. Cultura brasileira e indústria cultural. São Paulo: Brasiliense, 2001, $5^{\text {a }}$ ed.

PONTES, H. 1998. Destinos mistos: os críticos do grupo Clima em São Paulo (1940-1968). São Paulo: Companhia das letras.

PULICI, C. 2008. Entre sociólogos: versões conflitivas da "condição de sociólogo" na USP dos anos 1950-1960. São Paulo: Edusp.

RIDENTI, M. 2014. Em busca do povo brasileiro. Artistas da revolução, do CPC à era da TV. São Paulo: Unesp. 
RODRIGUES, L. M. 1981. “O PCB: os dirigentes e a organização”. In. FAUSTO, B. (org.). História geral da civilização brasileira. O Brasil Republicano. São Paulo: Difel, v. 3, t. 3.

RODRIGUES, L. S. 2012. "A produção social do marxismo universitário em São Paulo (1958-1978)". Tese de doutorado. FFLCH-USP.

ROMÃO, W. M. R. 2006. A experiência do Cesit: sociologia e política acadêmica nos anos 1960. São Paulo: Humanitas.

SADER, E. 1967. "Conflito industrial e luta de classes". Teoria e Prática, n. 2.

SEREZA, H. C. 2005. Florestan: a inteligência militante. São Paulo: Boitempo.

SOLA, L. 1966. “Durkheim: senso-comum e objetividade”. Teoria e prática, n. 2.

TARCUS, H. 2007. Marx en la Argentina. Sus primeros lectores, obreros, intelectuales y cientificos. Buenos Aires: Siglo XXI.

YMONET, M. 1984. "Les héritiers du capital. L'invention du marxisme en France au lendemain de la Commune". Actes de la recherche en sciences sociales, n. 55, nov. 